\title{
African Generation Y Students' Mobile Advertising Usage
}

\author{
KL Sharp \\ Vaal University of Technology \\ klsharp21@live.com \\ AL Bevan-Dye \\ North-West University (Vaal Triangle Campus) \\ ayeshabevandye@gmail.com or Ayesha.Bevandye@nwu.ac.za
}

\section{Doi:10.5901/mjss.2014.v5n21p85}

\begin{abstract}
The purpose of this study was to investigate African Generation Y students' mobile advertising usage in the South African context. In South Africa, the African Generation Y cohort represents the largest portion of the Generation $Y$ (individuals born between 1986 and 2005) cohort, and the potential future earning power and influential role of those who have a tertiary education, makes African university students a particularly attractive target market. A convenience sample of 600 African students across three South African registered public higher education institutions (HEls), situated in the Gauteng province, was taken. Self-administered questionnaires, designed to measure African Generation Y students' mobile advertising usage, were hand delivered to the students during class time at each of the three campuses. The data collected was analysed using a descriptive statistical analysis. The findings suggest that although African Generation $Y$ students are not willing to receive mobile advertisements on their phones on a daily basis, they do make use of mobile advertising, although the frequency and degree they read the mobile advertisement messages they receive varies considerably. This study contributes to the practice of marketing by assisting marketers in the understanding these African Generation Y students' mobile advertising usage, which will aid in developing appropriate mobile advertising strategies for reaching this cohort.
\end{abstract}

Keywords: Advertising; Mobile advertising usage; African Generation Y students; South Africa

\section{Introduction}

Africa is viewed as the next major market for mobile advertising, especially countries such as South Africa, Nigeria and Algeria that have particularly high mobile penetration rates (Magubane, 2013). The significant increase in mobile usage in South Africa has driven this increase in the level of mobile advertising in the country, which, in 2013, remained dominated by short message service (SMS) advertising (Effective Measure, 2014). As South African consumers increasingly use their mobile phones to do price comparisons prior to shopping, so the reach and volume of mobile advertising is becoming more effective (Magubane, 2013).

In comparison to conventional advertising, where consumers often receive advertisements for products and services that they are not interested in, the capabilities of mobile terminals provide marketers with a tool to address consumers individually. It also allows marketers to analyse their call patterns in order to send target-orientated and personalised advertisements to target consumers' mobile phones (Tsang, Ho \& Liang, 2004; Bulander, Decker, Schiefer \& Kolmel, 2005; Lee, Lee, Lee, Kim \& Lee, 2006; Carroll, Barnes, Scornavacca \& Fletcher, 2007).

Lee et al. (2006) point out that because of the different mobile advertising formats available and the rapid rate at which these are developing, the mobile platform is emerging as an interactive media, which, if implemented correctly, will enable marketers to target specific audience groups and provide instant feedback as to whether or not the message was successful in attracting a consumer. This suggests that mobile advertising is a highly targeted form of advertising, as well as a two-way dialogue between the brand and consumer, which may assist in building a personal relationship between the two.

A mobile advertisement may be presented in a text, image, message, link, video or audio format, which may be posted in a variety of advertisement spaces on mobile devices based on selected advertisement templates and spaces. This allows consumers who receive these mobile advertisements an opportunity to engage in discussions and transactions with marketers (Komulainen, Manela, Tahtinen \& Ulkuniemi, 2007; Gao \& Ji, 2008). 
Okazaki and Taylor (2008) indicate that even though there has been a significant increase in the ownership of mobile devices, there is no guarantee that consumers will readily accept mobile advertising. Gao and Ji (2008) suggest that certain technical challenges exist, which significantly affect consumers' acceptance of mobile advertisements. These technical challenges range from limited user interface, small screens, the absence of a full keyboard, as well as the low wireless Internet download speeds. As such, marketers need to create effective advertisements that are able to overcome these technical challenges.

Cleff (2007) and King and Jessen (2010) suggest that in order to ensure successful mobile advertising, and to provide more location-specific and personalised mobile advertisements, marketers need to profile consumers more precisely. This will allow for the creation of profiles, which could define and analyse consumers at any given time. With the use of profiling, marketers will be able to monitor when a consumer responds to a mobile advertisement, and update these profiles with the specific content related to a consumer's actions at any given time, making the managing of consumer profiles an on-going process.

According to Hudson (2013), these consumer profiles may be created on both individual devices and multiple devices by making use of various criteria, such as user, platform and location. Citrix (2013) adds that with all the developments in mobile technologies and the significant increase in the ownership of mobile devices, consumers are now able to access their desktops and applications from almost any device or location, indicating the need for the profiling of consumers to ensure they receive a consistent experience every time.

Swallow (2010) explains that options such as SMS, multi-media messaging (MMS), wireless application protocol (WAP), search aids, videos, push notifications, rich media and mobile application display advertisements make the landscape of mobile advertising complicated. Therefore, if not implemented correctly, mobile advertising may become a burden to consumers (Cleff, 2007). As such, marketers must pay special attention to the relevancy and utility of mobile advertisements to ensure that they provide consumers with useful information, and in a way to save them both time and money based on their personal profiles, situations and locations (Merisavo, Kajalo, Karjaluoto, Virtanen, Salmenlavi, Raulas \& Leppaniemi, 2007).

Mobile advertising has considerable potential to contribute to brand building, and when applied under the appropriate conditions, generates action and excitement (Okazaki \& Taylor, 2008). The use of celebrity endorsers or reference groups may also be a good tool to increase the effectiveness and adoption of mobile advertising (Soroa-Kaura \& Yang, 2010). Consequently, the success of mobile advertising largely depends on consumers' receptiveness towards it and, at present, research indicates that in comparison to older generations, the youth are more accepting of mobile advertisements (Muk, 2007).

\section{Growth in Mobile Advertising}

Owing to the cost effectiveness and highly personalised nature of mobile advertising, more and more organisations are recognising the benefits of implementing a mobile advertising campaign as part of their advertising strategy (Peacock, 2011). Of those marketers using mobile advertising, 70 percent use text messages, 31 percent use video advertisements and 36 percent use mobile search. It is estimated that 45 percent of marketers intend on implementing mobile search in the near future, resulting in approximately 55 percent of all marketers re-evaluating their budgets and changing their focus to increasing mobile advertising expenditure (Stamford, 2011).

At the beginning of 2011 more than 23.2 billion mobile advertisement banners were delivered across the entire network, representing a 38 percent increase from the end of 2010 (Lai, 2011). By the third quarter of 2011, more than 33.6 billion advertisement banners were delivered across the entire network, which housed over 8100 publisher sites, targeting over 300 million unique consumers per month (Pater, 2011). By the end of the first quarter of 2012, more than 45 billion advertisement banners had been delivered across the network, housing more than 10000 publisher sites (GoMo News, 2012). The top 20 ranked mobile advertising countries generated approximately 79 percent of all these served mobile advertisement banners, with India, Indonesia, the United States, Korea and South Africa dominating the top five positions.

The introduction of smartphones into South Africa has seen the number of South African mobile Internet users significantly increase as a direct result of cheaper Internet access, which has provided marketers with an opportunity to create interactive mobile advertising campaigns (Pater, 2011). By the end of 2011, there were approximately 8.5 million Internet users in South Africa, with more than 2.48 million of these individuals primarily using their mobile phones to gain access to the Internet. This, combined with the more affordable smartphones and cheaper data rates, is believed to be the most influential force behind the significant growth in mobile advertising in South Africa (Joss, 2012).

The response rate for mobile advertising campaigns in South Africa ranges from between 10 percent to 25 percent 
(Swallow, 2010). The possibilities of increased brand awareness, boosted revenue and improved customer loyalty, combined with the cost effectiveness of mobile advertising campaigns, highlight the importance of marketers allocating a portion of their digital advertising budgets to mobile advertising (Hallerman, 2012). Research indicates that 52 percent of brands are expected to commit 5 to 25 percent of their budgets to mobile advertising within the next five years (Nixon, 2013). Consequently, the mobile phone is considered the most exciting new advertising medium in South Africa.

Prabhudesai (2011) highlights that with 52 percent of all mobile users accessing the Internet being between the ages of 20 to 24 years, and a further 23 percent being between the ages of 25-29, it is evident that, compared to any other age cohort, the youth, known as Generation $Y$, use the mobile Internet and its various applications considerably more. Masote and Shevel (2012) add that due to the substantial growth in the youth market in South Africa there are now more sim cards and phone handsets per household. As such, mobile advertising is an effective avenue to this lucrative generation of young, urban and single consumers with substantial spending power (Baburajan, 2011).

As part of its strategy to move into multimedia and broadcasting, Vodacom, the market leader in South Africa's cellular service provider industry, now sells text advertisements on its free call-back service, and banner advertisements on its mobile Internet portals. These text advertisements are believed to generate up to 20 million messages per day and are able to reach both high- and low-end markets. Banner advertisements will be sold on Vodacom4me and Vodafone Live, which reportedly draw approximately 1.4 million users per month. These advertisements will offer consumers an optional click-through to a mobile website, allowing them to decide if they want to engage further with the brand (FrancePresse, 2013).

\section{Generation $Y$}

Kane (2012) and Markert (2004) identify Generation Y as all the individuals born between 1986 and 2005, which constitutes more than 70 million individuals. Being the first generation to have grown up in a world where computers, mobile phones, electronic devices and the World Wide Web have been integral elements of everyday life has led to these individuals thriving on technology and its innovations. With the use of laptops, mobile phones and a range of other gadgets, these individuals can be plugged in 24 hours a day, seven days a week, causing them to learn, process information at rapid speeds, perform well in their jobs, and lead intense social lives (Sheahan, 2005; Schwalbe, 2009; Schlitzkus, Schenarts \& Schenarts., 2010; Kane, 2012; Ellis-Christensen, 2013).

Growing up in such a media saturated, brand conscious world has enabled these individuals to stay abreast of the rapid rate of technological and social change, which has led to the dubbing of them as the elusive new youth market segment. As such, organisations will need to embrace these individuals to ensure future success, highlighting the importance of connecting with this new generation of consumers on their own turf. This has created the need for marketers to rethink their advertising strategies and avenues geared towards these individuals (Wolburg \& Pokrywczynski, 2001; Sheahan, 2005; Smith, 2012).

Although their resistance towards advertising efforts remains very similar to that of Generation $X$, the individuals of the Generation Y cohort respond differently towards the advertisements they receive (Wolburg \& Pokrywczynski, 2001). These individuals prefer images and graphics as opposed to text, they crave interactivity, and are more responsive to personalised advertisements (Schwalbe 2009; Smith 2012). In addition, these individuals are visual and contextual, and process information on an emotional level, forming opinions about products and services been advertised based more on what the product or service can do and its appearance, rather than on what marketers say about the product or service (Aquino, 2012). Therefore, although this cohort plays an important role in the advertising economy, the degree of difficulty involved in communicating with this cohort poses a threat to the success of many organisations' marketing efforts. This highlights the need for marketers to learn that it is not "how to reach consumers where they are" that is important, but rather "how to understand their mind-set and where they are going" (Martins, 2013).

Many organisations view the Generation $Y$ cohort as a homogenous market segment; however, the literature indicates that it is more of a heterogeneous market segment (Foscht, Schloffer, Maloles \& Chia 2009). Moreover, marketers are becoming aware that the purchasing habits of these individuals will have a significant impact in the years to come (Wolburg \& Pokrywczynski, 2001). The purchasing behaviours of these individuals are very computer-oriented, which may suggest that by implementing and using digital media, organisations may create a more appealing overall image and product or service offering (Malarchy, 2006).

Owing to their short attention spans and strong desire for complete information, marketers need to ensure that advertising campaigns targeted at the Generation $Y$ cohort do not prolong the facts in an attempt to create a sense of drama or omit information to generate mystery or consumer interest. Moreover, individuals in this cohort respond to advertisements that are "hip", with "edgy statements that cut through media clutter and push the boundaries of style and 
taste" (Markiewicz, 2003). As such, marketers should gear their advertising strategies towards anything that appears to be "new, advanced and computerised" (Malarchy, 2006).

In 2013, approximately 38 percent of the South African population were categorised as forming part of the Generation $Y$ cohort. In South Africa, the majority of this cohort (an estimated $83 \%$ ) is made up of Africans, rendering the country's African Generation Y cohort a significantly sized market segment (Statistics South Africa, 2013). Those African Generation $Y$ members engaged in tertiary education represent an especially important segment, given that higher education often translates into higher future earning potential and a higher social status within a community (Bevan-Dye \& Suruijlal, 2011). Studies that focus on students at tertiary institutions typically define them as individuals between the ages of 18 and 24 (Wolburg \& Pokrywczynski, 2001; Steel, 2012).

In South Africa, African who are well educated, have well-paying occupations, and who are credit-worthy are labelled the Black Diamonds. In all likelihood, African Generation $Y$ individuals with a tertiary education will one day become Black Diamonds (Herman, 2006; Comins, 2007). In the last eight years, the Black Diamond segment in South Africa has increased from 8 percent to 16 percent of the population segment, and its spending power has increased to R400 billion (Radebe, 2013). Black Diamonds are a group of individuals characterised by a certain amount of education, wealth, and other middle-class determining factors (Herman, 2006). Higher education levels, credit, black economic empowerment (BEE) and economic growth have all contributed to the growth in this African middle class (Radebe, 2013). Shevel (2013) indicates that in 2013, 95 percent of South Africa's Black Diamonds owned a mobile device, which is a significant increase from the 65 percent in 2004. As future Black Diamonds, African Generation Y individuals engaged in tertiary education constitute an important segment to marketers in the South African market.

\section{Methodology}

\subsection{Sample}

The sample frame for this study constituted the 23 public registered higher education institutions (HEIs) in South Africa in 2013. From the original sampling frame, a non-probability judgement sample of three HEls, located in the Gauteng province, was taken to narrow the sampling frame- one comprehensive university campus, one traditional university campus and one university of technology campus. The Gauteng province was selected over other provinces in the country because it comprises the largest share of the South African population. Approximately 12, 7 million people, equivalent to 24 percent of the South African population, live in Gauteng (Statistics South Africa, 2013).

A non-probability, convenience sample of 600 full-time undergraduate African Generation $Y$ students was used to conduct the study. Lecturers at each of the three campuses were contacted and asked if they would allow the questionnaire to be distributed to their students during or after lectures. Once permission was obtained from the lecturer, a self-administered questionnaire was distributed to the full-time African Generation $Y$ undergraduate students during or straight after class time at each of the three campuses.

\subsection{Research instrument}

In accordance with the objectives of the study, the questionnaire used included two sections namely Section A, which was designed to gather demographic data and Section B where three scales were used, to determine participants' mobile advertising usage. These scales were designed to determine how often African Generation Y students were prepared to receive mobile advertisements (four items), how often they read these advertisements (five items) and how much of the advertisement they read (five items).

\section{Results}

Given that the completion of the questionnaire was voluntary, a relatively high response rate of 75.83 percent was achieved. Respondents ranged from 18 to 24 years of age. With the exception of the Northern Cape and the Western Cape, each of South Africa's nine provinces was represented. The majority of respondents indicated their province of origin to Gauteng (57\%), followed by Free State (11\%). The sample contained more female respondents (61\%) than male respondents (39\%). Demographic information for respondents is provided in Table 1. 
Table 1. Sample description

\begin{tabular}{cccclc}
\hline Age & Percent (\%) & Gender & Percent (\%) & Province & Percent (\%) \\
\hline 18 & 11 & Female & 61 & Gauteng & 57 \\
19 & 20 & Male & 39 & Free State & 11 \\
20 & 21 & & & Limpopo & 10 \\
21 & 19 & & Mpumalanga & 9 \\
22 & 16 & & North West & 6 \\
23 & 7 & & KwaZulu-Natal & 5 \\
24 & 5 & & Eastern Cape & 3 \\
& & & Northern Cape & 0 \\
& & & Western Cape & 0 \\
\hline
\end{tabular}

In addition to the demographic questions, the particiapants were asked three questions designed to determine their mobile advertising usage. The first question asked how often participants were willing to receive mobile advertisements. Of the participants, 75 percent indicated being willing to receive mobile advertisements less than once a day, 17 percent twice a day, 5 percent three times a day and 2 percent more than four times a day. African Generation $Y$ students willingness to receive mobile advertisments is reported on in Table 2.

Table 2. Willingness to receive mobile advertisments

\begin{tabular}{lc}
\hline How often are you willing to receive mobile advertisements? & Percent $\%$ \\
\hline Less than once a day & 75 \\
Twice a day & 17 \\
Three times a day & 5 \\
More than four times per day & 2 \\
\hline
\end{tabular}

In terms of the frequency African Generation $Y$ students read the mobile advertisements they receive, 26.4 percent of the participants indicated that they ignore the mobile advertisements they receive, 37.6 percent read them occasionally, 4.2 percent read them after accumulating too many, 15.8 percent read them when they get time and 14.9 percent read them right away. These findings are summarised in Table 3.

Table 3. Frequency of reading received mobile advertisements

\begin{tabular}{lc}
\hline How often do you read the mobile advertisements you receive? & Percent \% \\
\hline Ignore the mobile advertisements completely & 26.4 \\
Occassionally read the mobile advertisments & 37.6 \\
Read the mobile advertisements after accumulating too many of them & 4.2 \\
Read the mobile advertisements when they get time & 15.8 \\
Read the mobile advertisements right away & 14.9 \\
\hline
\end{tabular}

With regards to how much of mobile advertisements African Generation $Y$ students read, 22 percent of the participants indicated that they read none of the mobile advertisement messages they receive, 35 percent indicated that they read about a quarter, 13 percent read about half, 5 percent about three-quarters, and 23 percent indicated that they read the whole mobile advertisement message. This information is sumarised in Table 4.

Table 4. Degree to which mobile advertisements are read

\begin{tabular}{lc}
\hline How much of your received mobile advertisements do you read? & Percent \% \\
\hline Read none of the mobile advertisement message & 22 \\
Read about a quarter of the mobile advertisement message & 35 \\
Read about half of the mobile advertisement message & 13 \\
Read about three-quarters of the mobile advertisement message & 5 \\
Read the whole mobile advertisement message & 23 \\
\hline
\end{tabular}




\section{Discussion}

The purpose of this study was to measure African Generation Y students' mobile advertising usage. The findings suggest that the majority of African Generation $Y$ students would be willing to receive mobile advertisement messages less than once a day, which suggests that excessive mobile advertising might result in irritation, which would negatively influence their attitudes towards mobile advertising. This may in turn negatively influence their attitudes towards the brand being advertised. As such, marketers need to balance the reach and frequency of their mobile advertising efforts carefully.

In terms of how often African Generation Y students read mobile advertisements, even though a significant number indicated they ignored them completely, over 70 percent indicated that they did read them, at least occasionally. In order to encourage readership of mobile advertisements, marketers need to endeavour to make these messages more interesting and relevant to this age cohort. They should also make use of the personalisation feature of mobile advertising and address the individual by name. In addition, given that the new mobile smartphones are typically equipped with a global positioning system (GPS), targeting consumers with location-based mobile advertisements may serve to make the message more relevant and valuable to its audience.

Whilst the vast majority of African Generation $Y$ students indicated that they read at least a portion of the mobile advertisements that they receive, over 30 percent indicated that they read only a quarter of the message. This suggests that marketers should employ the same wisdom utilised for billboard advertising in their mobile advertising efforts - keep the message short. Furthermore, the findings suggest that marketers should make use of the primacy order effect and make their most important point or strongest argument at the start of the message in order to attract the attention of their target audience.

\section{Limitations and Future Research}

This study measured African Generation Y students' mobile advertising usage. This study, like most studies, has certain limitations, which may present several future research opportunities. The first limitation is that the study made use of a non-probability convenience sampling method to conduct the survey. As such, care should taken when interpreting the study's results. In addition, a single cross-sectional research design was used in this research study. Consequently, the research study's findings lack the depth of a longitudinal study. Future research, in the form of a longitudinal study, would provide valuable information concerning any changes in the usage of mobile advertising by African Generation $Y$ students. A second limitation of the study is that it only focused on African Generation Y individuals aged between 18 and 24. It would be interesting to determine younger African Generation $Y$ members' mobile advertising usage, as well as the level of usage by other generations alive today. Research focusing on the factors that determine the African Generation $Y$ cohort's attitude towards mobile advertising would be particularly valuable in uncovering the best way of using mobile advertising to target this segment.

\section{Conclusion}

In conclusion, the significant developments in and rapid adoption of mobile technologies have led to the development and introduction of mobile advertising, which has altered the world of marketing in many ways. The success of mobile advertising largely depends on consumers' receptiveness towards it and, at present, research indicates that in comparison to older generations, the youth are more accepting of mobile advertisements. The current study expands on consumer mobile advertising usage by looking at the African Generation Y cohort within the South African context. As Generation $Y$ consumers represent the future, it is important for marketers to understand these consumers' mobile advertising usage in order to develop appropriate mobile advertising strategies. The findings of this study suggest that mobile advertising messages using the SMS format should be kept short and relevant, and that the strongest point in the message should be put first. In addition, there should be a careful balance concerning the reach and frequency of mobile advertisements.

\section{References}

Aquino, J. (2012). Gen Y: the next generation of spenders. [Online] Available: http://www.destinationcrm.com/Articles/Editorial// Magazine-features/Gen-Y-The-Next-Generation-of-Spenders-79884.aspx (August 9, 2013).

Baburajan, R. (2011). Mobile marketing: the next boom. [Online] Available: http://www.biztechreport.com/story/1193-Mobile-MarketingNext-Boom (April 17, 2013). 
Bevan-Dye, A.L. (2013). Black Generation Y students' attitudes towards Web advertising value. Mediterranean Journal of Social Sciences, 4(2),155-164.

Bulander, R., Decker, M., Schiefer, G. \& Kolmel, B. (2005). Comparison of different approaches for mobile advertising. IEEE Internal Workshop on Mobile Commerce and Services.

Carroll, A., Barnes, S.J., Scornavacca, E. \& Fletcher, K. (2007). Consumer perceptions and attitudes towards SMS advertising: recent evidence from New Zealand. International Journal of Advertising, 26(1), 79-98.

Citrix. (2013). Profile Management. [Online] Available: http://www.citrix.com/go/jmp/upm (July 9, 2013).

Cleff, E.B. (2007). Mobile advertising regulation: Implementing the legal criteria of meaningful consent in the concept of mobile advertising. Computer Law \& Security Report, 23, 262-269.

Comins, L. (2007). Black diamonds' drive economy. [Online] Available: http://www.iol.co.za/news/south-africa/black-diamonds-driveeconomy-1.357317 (March 6, 2012).

Effective Measure. (2014). South Africa mobile report. March, 2014. [Online] Available: http://www.effectivemeasure.com/south-africanmobile-report-march-2014 (July 9, 2014).

Ellis-Christensen, T. (2013). What is Generation Y? [Online] Available: http://wisegeek.org/what-is-generation-y.htm (August 22, 2013).

Foscht, T., Schloffer, J., Maloles, C. \& Chia, S.L. (2009). Assessing the outcomes of Generation-Y consumers' loyalty. International Journal of Bank Marketing, 27(3), 218-241.

France-Presse, A. (2013). Mobile phone industry predicts 4 billion subscribers by 2018. [Online] Available: http://www.rawstory.com/rs/ 2013/02/25/mobile-phone-industry-predicts-4-billion-sunscribers-by-2018 (April 17, 2013).

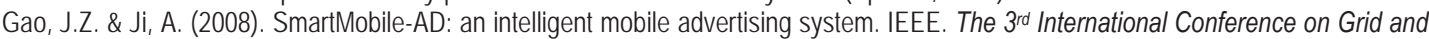
Pervasive Computing Workshops, 54(3), 164-171.

GoMo News. (2012). Mobile advertising sees tremendous growth says Buzzcity. [Online] Available: http://www.gomonews.com/mobileadvertising-sees-tremendous-growth-says-buzzcityl (September 7, 2013).

Hallerman, D. (2012). Smartphones, mobile Internet set stage for increased mobile ad spend. [Online] Available: http://www.emarketer.com/Article/Smartphones-Mobile-Internet-Set-Stage-Increased-Mobile-Ad-Spend/1008622 (September 18, 2012).

Herman, D. (2006). "Black diamonds" are misunderstood survey. [Online] Available: http://www.iol.co.za/news/south-africa/blackdiamonds-are-misunderstood-survey-1.282308 (March 6, 2012).

Hudson, B. (2013). Dell KACE K3000 mobile management appliance. http://www.kace.com/products/mobile-managment-aplliance/ feature/Mobile-Device-Filtering (July 9, 2013).

Joss, E. (2012). How South Africans use cell phones/ smartphone usage [Inforgraphic]. [Online] Available: http://www.xcellentmedia. co.za/blog/how-south-africans-use-cell-phones-infographic/ (July 9, 2013).

Kane, S. (2012). Generation Y. [Online] Available: http://legalcareers.about.com (June 25, 2012.

King, N.J. \& Jessen, P.W. (2010). Profiling the mobile customer- privacy concerns when behavioural advertisers target mobile phonespart 1. Computer Law \& Security Review, 26, 455-478.

Komulainen, H., Manela, T., Tahtinen, J. \& Ulkuniemi, P. (2007). Retailers' different value perceptions of mobile advertising service. International Journal of Service Industry Management, 18(4), 368-393.

Lai, K.F. (2011). The BuzzCity report: a quarterly briefing on the mobile Internet, 1(2). [Online] Available: http://www.loyokezie.com/wpcontent/uploads/2011/05/The-BuzzCity-Report-Q2-2011.pdf (February 14, 20130.

Lee, H.S., Lee, C.H., Lee, G.H., Kim, Y. \& Lee, B.G. (2006). Analysis of the actual response rates in mobile advertising. International Conference on Innovations in Information Technology. [Online] Available: http://academic.reserach.microsoft.com/publication/ 50520521/analysis-of-the-actaul-response-rates-in-mobile-advertising (February 18, 2013).

Magubane, K. (2013). Africa is next major mobile advertising market, says BuzzCity. Business Day Live, 22 February. [Online] Available: http://www.bdlive.co.za/business/media/2013/02/22/africa-is-next-major-mobile-market-says-buzzcity (July 9, 2014).

Malarchy, S. (2006). Marketing to Generation Y: the "Echo Boomers". [Online] Available: http://voices.yahoo.com/marketing-generationy-echo-boomers-38136.html?cat=3 (August 22, 2013).

Markert, J. (2004). Demographics of age: generational and cohort confusion. Journal of Current Issues and Research in Advertising, 26(2), 11-25.

Markiewicz, P. (2003). Who's filling Gen-Y's shoes? [Online] Available: http://www.brandchannel.com/features_effects.asp?pf_id=156 (August 22, 2013).

Martins, C. (2013). Mobile influence: the new power of the consumer webinar overview. http://www.scoop.it/t/consumer-behaviour-onweb/p/1221589190/ (August 22, 2013).

Masote, M. \& Shevel, A. (2012, March 11). MTN unlikely to unplug Iran. Sunday Times, Business Times, p. 11.

Merisavo, M., Kajalo, S., Karjaluoto, H., Virtanen, V., Salmenlavi, S., Raulas, M \& Leppaniemi, M. (2007). An empirical study of the drivers of consumer acceptance of mobile advertising. Journal of Interactive Advertising, 7(2), 41-50.

Muk, A. (2007). Consumers' intention to opt into SMS advertising: a cross-national study of young Americans and Koreans. International Journal of Advertising, 26(2), 177-198.

Nixon, C.W. (2013). Social media marketing ranks as b2b marketers' most popular tactics. [Online] Available: http://www.scoop.it/t/ emerging-themes-in-marketing?page=3 (April 17, 2013).

Okazaki, S. \& Taylor, C.R. (2008). What is SMS advertising and why do multinationals adopt it? Answers from an empirical study in European markets. Journal of Business Research, 61, 4-12. 
Pater, D. (2011, May 29). Smartphones drive net access. Sunday Times, Money and Careers, p. 1.

Peacock, B. (2011, October 23). Why broadband is going mobile: Africa abandons fixed lines in favour of surfing on handheld devices. Sunday Times, p. 1.

Prabhudesai, A. (2011). Mobile Advertising witnesses tremendous growth- Gen Y dominate usage. [Online] Available: http://trak.in/tags/business (February 13, 2013).

Radebe, K. (2013). Young, middle class and black. [Online] Available: http://www.moneyweb.co.za/moneyweb-economic-trends/youngmiddle-class-and-black (October 24, 2013).

Schlitzkus, L.L., Schenarts, K.D. \& Schenarts, P.J. (2010). Is your residency program ready for Generation Y? Journal of Surgical Education, 67(2), 108-111.

Schwalbe, C.B. (2009). Leveraging the digital media habits of the millennials: strategies for teaching journalism courses. South Western Mass Communication Journal, 53-68.

Sheahan, P. (2005). Generation Y: thriving and surviving with Generation Y at work. Victoria: Hardie Grant Books.

Shevel, A. (2013). Black diamonds outshine whites. [Online] Available: http://www.bdlive.co.za/national/2013/04/28/black-diamondsoutshine-whites (October 24, 2013).

Smith, K.T. (2012). Longitudinal study of digital marketing strategies targeting millennials. Journal of Consumer Marketing, $29(2), 86-92$.

Soroa-Kaura, S. \& Yang, K.C.C. (2010). Factors affecting consumers' responses to mobile advertising from a social norm theoretical perspective. Telematics and Informatics, 27, 103-113.

Stamford, C. (2011). Gartner says worldwide mobile advertising revenue forecast to reach \$ 3.3 billion in 2011. [Online] Available: http://www.gartner.com/newsroom/id/1726614 (September 18, 2012).

Statistics South Africa. (2013). Mid-year population estimates: 2013 key indicators, statistical estimates: 2011 key indicators, statistical release P0302. [Online] Available: http://www.statssa.gov.za (September 4, 2013).

Steel, C. (2012). Generation Y- Great Britain's worst environmental offender. [Online] Available: http://www-03.ibm.com/press/uk/ en/pressrelease/28241.wss (March 6, 2012).

Swallow, E. (2010). Top 5 mobile advertising trends to watch. [Online] Available: http://mashable.com/2010/08/19/mobile-advertisingtrends (April 17, 2013).

Tsang, M.M., Ho, S. \& Liang, T. (2004). Consumer attitudes towards mobile advertising: an empirical study. International Journal of Electronic Commerce, 8(3), 65-78.

Wolburg, J.M. \& Pokrywczynski, J. (2001). A psychographic analysis of Generation Y college students. Journal of Advertising Research, 33-52. 